\title{
HEALTHY LIFESTYLE AND OPINION SEEKING IN THE CONSUMPTION OF FOOD SUPPLEMENTS
}

\author{
ESTILO DE VIDA SAUDÁVEL E BUSCA DE OPINIÃO NO \\ CONSUMO DE SUPLEMENTOS ALIMENTARES
}

Submission: $25 / 05 / 20$ Accept: 22/04/21

\author{
Jeferson Mendonça Pereira Filho ${ }^{1}$ \\ Marconi Freitas da Costa ${ }^{1}$ \\ Jonas Alves Cavalcanti ${ }^{1}$ \\ 1 Universidade Federal de Pernambuco. Caruaru, Caruaru, Brazil.
}

\begin{abstract}
Purpose - This research aimed to verify the influence of healthy lifestyle and the search for opinion in relation to the intention to consume food supplements.

Design/methodology/approach - A descriptive research was carried out using a quantitative approach. The field research was developed through an online survey and the data were analyzed using multiple linear regression.

Findings - It was found that the higher the level of healthy lifestyle, the greater the intention to resort to food supplementation. Furthermore, the search for opinion, in turn, positively influenced the intention to consume food supplements. However, this search for opinion is intrinsically related to the search for information from sources not indicated to direct the consumption of dietary supplements, which represents a risk to health.

Originality/value - The main contribution of this research was that the experience of a healthy lifestyle does not represent the absence of consumption of dietary supplements. The results reveal an alarming situation regarding the health risks to which consumers of dietary supplements are exposed. These risks are also related to people with a high level of healthy lifestyle. Thus, this picture represents a public health problem and refers to the urgent need for information and awareness-raising actions for the population in order to control the incidence of diseases associated with the consumption of these products.
\end{abstract}

Keywords - Food supplements; Healthy lifestyle; Opinion seeking; Health risk; Public health 


\section{RESUMO}

Objetivo - Esta pesquisa teve como objetivo verificar a influência do estilo de vida saudável e a busca de opinião em relação à intenção de consumir suplementos alimentares.

Desenho / metodologia / abordagem - Foi realizada uma pesquisa descritiva com abordagem quantitativa. A pesquisa de campo foi desenvolvida por meio de um survey online e os dados foram analisados por meio de regressão linear múltipla.

Resultados - Constatou-se que quanto maior o nível de estilo de vida saudável, maior a intenção de recorrer à suplementação alimentar. Além disso, a busca de opinião, por sua vez, influenciou positivamente a intenção de consumir suplementos alimentares. No entanto, essa busca de opinião está intrinsecamente relacionada à busca de informações em fontes não indicadas para direcionar o consumo de suplementos alimentares, o que representa risco à saúde.

Originalidade / valor - A principal contribuição desta pesquisa foi que a vivência de um estilo de vida saudável não representa a ausência de consumo de suplementos alimentares. Os resultados revelam uma situação alarmante em relação aos riscos para a saúde a que estão expostos os consumidores de suplementos alimentares. Esses riscos também estão relacionados a pessoas com alto nível de estilo de vida saudável. Assim, esse quadro representa um problema de saúde pública e remete à necessidade urgente de informações e ações de conscientização da população a fim de controlar a incidência de doenças associadas ao consumo desses produtos.

Palavras-chave - Suplementos alimentares; Estilo de vida saudável; Busca de opinião; Risco de vida; Saúde pública.

\section{INTRODUCTION}

The World Health Organization (WHO) has declared obesity to be the epidemic of the 21st century. Also according to the WHO, food problems have an important impact on chronic diseases, health costs, quality of life and public health (Azila Mohd Noor, Yap, Liew \& Rajah, 2014; Küster-Boluda \& Vidal-Capilla, 2017). In this context, the consumption of dietary supplements in the world has increased, since many users believe in the benefits that these products can bring, including for weight reduction (Homer \& Mukherjee, 2018). Consumers commonly see these products as a simple, quick and easy way to lose weight, often believing that they are absolutely safe (Vaughan et al., 2017).

Food supplements are defined as food compounds that contain one or more ingredients, such as vitamins, minerals, herbs, amino acids or other substances intended to supplement the diet (Friedman, Birstler, Love \& Kiefer, 2019). They fall into this category, for example: thermogenic, vitamin compounds, Whey Protein and essential fatty acids. Additionally, as highlighted by Bessada, Alves and Oliveira (2018), these products are in demand among those who want to change their bodies through food, especially young people, since they overvalue their body image and are increasingly dissatisfied with the perception of how they look alike (Sarwer et al., 2005).

With this, it is known that individuals who are dissatisfied with their bodies seek various ways to achieve an ideal body and try to improve their appearance through plastic surgery, exercises and diets (Fuller-Tyszkiewicz et al., 2020). In turn, diets, in relation to plastic surgery and exercise, gain prominence for being an attempt to improve appearance in an easy and inexpensive way. However, commonly, the health risks associated with a diet, especially when composed of alternates food, they are disregarded (Molin et al., 2019). As a result, the consumption of dietary supplements has become a public health problem, considering the high number of people consuming these products on their own initiative or on the recommendation of friends without the due recommendation of a specialized professional (Molin et al., 2019). 
In the literature it is possible to verify that the indiscriminate use of supplements can generate complications for its users, for example, supplements sold for weight loss have been associated with adverse events such as chronic diarrhea, constipation, dehydration, metabolic acidosis , cardiac arrhythmia , ischemic stroke and hemorrhagic and hepatic and renal failure (Stickel \& Shouval, 2015). In this context, even though it is seen by many as an alternative for health promotion, the consumption of dietary supplements can cause several health problems, including, which can cause death (Flora Or, Yongjoo Kim, Juliana Simms \& Bryn Austin, 2019). So, what could be an ally, becomes a villain for health.

Nevertheless, on the part of the media, there is a great exposure of advertisements and information on food supplements, that is, the use of advertising creates confusion about the composition and usefulness of food supplements (DeLorme et al., 2012). In addition, due to the lack of regulatory standards and ineffective inspection in this segment, the use of advertisements with claims about certain ingredients is often not always true. According to Molin et al. (2019) these commercial appeals aim to induce consumers to buy or, furthermore, to promote the false image that the product works. Therefore, in the midst of this confusing and unsafe scenario, it is understood that the consumer of food supplements, in order to minimize the risks of a possible purchase, is encouraged to seek information about products in this category.

This information, commonly, in the segment of dietary supplements, comes from personal opinions (Whitehouse \& Lawlis, 2017). Opinions are judgments or thoughts issued by others that may influence the consumption intention (Assael, 1987). Thus, Suh and Lim (2014) state that the greater the consumers' knowledge about the products, the lower the perceived risk. Therefore, it is understood that one of the ways to increase the level of knowledge of young consumers of dietary supplements would be the opinion seeking (Flynn, Goldsmith \& Eastman, 1996). In other words, this opinion seeking is understood as an active action to use interpersonal sources to reduce the perceived risk in relation to the consumption of dietary supplements.

On the other hand, due to the damage to health that the use of nutritional supplements can bring, as well as the insecurity passed through media exposures about these products, it is understood that a healthy lifestyle is not associated with this reality. Therefore, according to Downes (2008), a healthy lifestyle involves physical activities and certain eating habits, such as the consumption of fruits and vegetables daily. Thus, it is suggested that even products identified as health aids, such as dietary supplements, will not be consumed by subjects who have a healthy lifestyle, since such individuals have a diet that meets the basic needs of nutrition (Mai \& Hoffmann, 2012).

From the above, it is understood that it is extremely important to study this phenomenon: consumption of dietary supplements. Thus, the reasons why consumers use food supplements need to be understood to deal with the unsafe use of these products. Studying the behavior of consumers of dietary supplements is an attempt to contribute to the mitigation of problems related to the health of Brazilians who consume or intend to consume products of this kind. Therefore, it is known that many aspects contribute to the intention to consume food supplements (Rocha et al., 2016). However, in Brazil, research aimed at this segment are still incipient in the field of applied social sciences, especially in the case of consumer behavior study.

Therefore, from the bibliographic research carried out for this investigation, the presence of theoretical models that intend to understand consumer behavior from the influence of constructs such as healthy lifestyle and opinion seeking was not identified. Thus, it is understood that there is a theoretical gap that justifies the initiative of this investigation. In summary, it is believed that individuals who have a healthy lifestyle tend not to consume food products that pose a risk to their health, including food supplements. In addition, the opinion seeking is expected to influence the intention to consume food supplements. 
Therefore, this research intends to analyze factors that influence the intention to consume food supplements. Specifically, it is intended to verify the influence of healthy lifestyle and the opinion seeking in relation to the intention to consume food supplements. Finally, this article is structured with this brief introduction, with the next topic addressing the theoretical framework, followed by the topic of the research method. Then, the analysis and discussion of the results is presented, ending with the conclusion of the study. Paragraph: use this for the first paragraph in a section, or to continue after an extract.

\section{THEORETICAL BACKGROUND}

This section of the article discusses the consumption of Major Food supplements in Brazil and presented a review of previous research of dietary supplements so that then be done by mapping a conceptual framework, to justify the theoretical relationships between the main constructs of interest.

\section{Consumption of food supplements in Brazil}

This study starts from the concept that food supplements are food products that can be concentrated sources of nutrients (vitamins and minerals) or other substances (amino acids, essential fatty acids, fibers, plants and plant extracts) with a nutritional or physiological effect, alone or in combination (Bessada, Alves \& Oliveira, 2018). In fact, the term "supplement" means "something that completes or makes an addition" (Merriam-Webster Online, 2019). Thus, it is possible to state that the food supplement can be identified as a complementary part of a diet in order to maintain good health (Azila Mohd Noor et al., 2014).

In Brazil, according to the Ministry of Health (BRASIL, 2017), 56.6\% of the adult population is overweight, which ends up being a reason for the growth in demand for dietary supplements, especially those that speed up metabolism (BrasNutri Online, 2019; Euromotor, 2019). In addition to their possible contribution to the weight reduction process, these products are used to achieve goals related to body aesthetics, such as gaining muscle mass (Bessada, Alves \& Oliveira, 2018). However, among young people, there is the largest share of consumers of dietary supplements in the country (Euromotor, 2019).

For the National Health Surveillance Agency (ANVISA), a control and inspection body under the Ministry of Health of Brazil, food supplements are not medicines and, therefore, are not used to treat, prevent or cure diseases, since their purpose is to provide nutrients, bioactive substances , enzymes or probiotics in addition to the diet of healthy individuals (ANVISA, 2019). Furthermore, in the case of the segment of products intended for food supplementation, in 2018, the country's first regulation on these products was created. This achievement helped protect consumers and ensure that accurate information is on product labels. With this change, products that are already on the market will have five years to adapt to the new requirements. The new ones will have to go to the shelves adjusted to the rule (ANVISA, 2018).

According to the Brazilian Association of Manufacturers of Nutritional Supplements and Foods for Special Purposes (BrasNutri), after the USA, the Brazilian population is the one that most consumes food supplements in the world (BrasNutri Online, 2019). These supplements are seen as an alternative to achieve goals related to body aesthetics (e.g., weight loss and muscle mass increase) and also as a form of health promotion (Bessada, Alves \& Oliveira, 2018). Thus, many young people resort to dietary supplementation as a strategy to achieve aesthetic goals quickly and comfortably (Bessada, Alves \& Oliveira, 2018). However, for Flora Or et al. (2019) it is likely that the food supplement users, 
particularly young people, have little awareness of the health risks associated with consumption of these products.

\section{Healthy lifestyle}

The increase in consumption intention can occur when products are presented as healthy and have favorable nutritional information (Küster-Boluda \& Vidal-Capilla, 2017). Thus, health-related aspects are also important in understanding the behavior of consumers of dietary supplements, given that products of this kind are commonly advertised as promoters of health and well-being. However, for Chandon and Wansink (2007) the fact that foods or products are shown to be healthy, even if they are not, is not enough for the consumption of these products by individuals concerned with health.

In this sense, Li and $\mathrm{Hu}(2018)$ state that one of the factors that shape well-being and quality of life is the concern with nutrition and the practice of physical activities. This implies, according to the authors, to develop a dietary routine without the presence of products rich in pesticides and that cooperate to increase the level of fat in the blood, as well as perform physical activities regularly. In this perspective, Downes (2008) states that a healthy lifestyle involves regular physical activities and the presence of certain eating habits, such as eating fruits and vegetables daily and the rejection of fatty foods.

Thus, a healthy lifestyle for consumers affects the attitude and consumption of foods perceived as healthy. For example, from the study of Zandstra, De Graaf and Van Staveren (2001) it is possible to state that concern for health and a healthy lifestyle are indicators of eating behavior and the desire to eat healthy foods (Küster-Boluda \& Vidal-Capilla, 2017; Li \& Hu, 2018). Therefore, consumers who are concerned about health end up showing eating behaviors where they avoid buying products with substances that can be found in natural foods (Mai \& Hoffmann, 2012).

Therefore, the use of dietary supplements should not be planned as a substitute for a healthy and appropriate diet, since it is understood as a healthy diet as a nutritional regime that allows a person to satisfy their energy and nutritional needs. Based on this understanding, according to the studies by Alkhatib, Seijo, Larumbe and Naclerio (2015), a healthy diet (rich in fruits, vegetables, vegetables and proteins) together with the practice of regular physical activity are the best tools for reducing excess weight and promotion of health and well-being. Therefore, it is understood that those who have a healthy lifestyle will not seek, in addition to these tools, alternatives that may be unsafe with regard to health preservation, such as the use of dietary supplements.

Thus, based on the understanding that a healthy lifestyle implies the practice of physical activities regularly, the presence of a diet rich in foods such as fruits and vegetables and the rejection of fatty and ultra-processed products (Marques, Peralta, Santos, Martins \& Gaspar de Matos, 2019) it is understood that such followers of this lifestyle will also avoid consuming products that may pose health risks, even with an inverse proposal, such as food supplements. From the above, as the first hypothesis of this study, it is stated that:

H1- The higher the level of the consumer's healthy lifestyle, the lower the intention to consume food supplements.

\section{Opinion seeking}

The main reasons that lead the population to consume food supplements are: social stigma of obesity, search for a quick solution for weight loss, easier access than consulting a doctor or nutri- 
tionist, without the need for a prescription, and supplements do not they require lifestyle changes that include diet and physical exercise (Saper, Eisenberg \& Phillips, 2004; Marques et al., 2019). This wrong assumption coupled with easy access to aggressive advertising contribute to the high popularity of food supplements (Alkhatib, Seijo, Larumbe \& Naclerio, 2015).

As a result of this fact, the consumption of food supplements is often made without the guidance of a professional able to recommend such products. As a result, those who do so may experience ignorance and lack of understanding about the types of supplements and their functionalities (Starr, 2015; Stafford, 2016). Furthermore, according to Azila Mohd Noor et al. (2014), younger consumers who take food supplements were strongly influenced by their parents to do so. However, in addition to family members, friends and Internet opinion leaders are also sources of information that young people frequently seek when they seek an opinion on dietary supplementation (Gan et al., 2011; Jain \& Katarya, 2019).

In addition, according to Stafford (2016), the influence of publicity and advertising aimed at this market segment, that is, supplement advertisements and information provided by the various media would be the main responsible for consumers' perception of dietary supplements. In this perspective, based on the research findings of DeLorme et al. (2012) it is possible to affirm that, due to the great exposure of advertisements and information about dietary supplements, advertising often creates confusion among consumers of these products in relation to several criteria such as: origin, efficiency, safety and method of use (Mai \& Hoffmann, 2012).

With that, from the moment these subjects are exposed to information about dietary supplements, through the most diverse communication channels (TV, internet, radio, etc.) and are influenced by the most varied reference groups (such as family and friends), such consumers, being confused or insecure, take an action to seek information in order to receive guidance on this subject (Jain \& Katarya, 2019). Thus, this search for guidance by other people is called an opinion seeking.

In the case of opinion seeking, it is important to highlight two fundamental elements: the existence of the opinion leader and the motivation to seek an opinion. For Engel et al. (1990) the existence of opinion leadership is based on the idea that other people seek opinions. Therefore, there is only one opinion leader (influencer) because there is a demand for opinion. Nevertheless, for Flynn, Goldsmith and Eastman (1996), consumers seem to rely more on the opinions of others than on sources of information originating from advertising or transmitted by mark eting professionals. Also according to the authors and corroborating this idea, for Jain and Katarya (2019), interpersonal sources are useful to reduce the perceived risk and strengthen the choices.

In addition, the opinion seeking is considered of great importance in the collection of information about the intended consumption (Jain \& Katarya, 2019). Regarding the motivation to seek opinions, consumers seek opinions to make more satisfactory decisions (Punj \& Staelin, 1983) and reduce the perceived risk in relation to consumption / purchase (Assael, 1987; Luqiu et al., 2019). That is, the information resulting from the opinion seeking can serve as a subsidy for strengthening a position in relation to consuming a certain product / service (Flynn, Goldsmith \& Eastman, 1996; Luqiu et al., 2019).

Thus, with regard to the consumption of dietary supplements, many times, as a way to achieve a perfect body and in view of the vulnerability of this public to the various information given by the media, it is understood that the opinion seeking is a resource for strengthening an attitude towards these products. Therefore, in this research, the opinion-seeking construct is understood as a possible influence on the intention to consume food supplements. Therefore, as the second research hypothesis of this study, it is stated: 
H2 - The higher the level of opinion seeking on food supplements, the greater the intention to consume them.

\section{Proposed theoretical model}

The intention to consume food supplements may be subject to the influence of some behavioral attributes of the consumer. Therefore, due to the risks that food supplementation can cause to health (Flora Or et al., 2019), it is possible that the intention to consume food supplements is influenced by those who have a healthy lifestyle and those who seek opinion on these products. That is, it is expected that individuals who have a higher level of healthy lifestyle (Downes, 2008) will not intend to consume food supplements. In addition, it also assumes that the higher for the search level of review (Flynn, Goldsmith \& Eastman, 1996) of most individuals is intended to consume food supplements. In view of the above, the theoretical model of this investigation was developed, as shown in Figure 1, synthesizing the relationships between these constructs.

Figure 1. Proposed theoretical model.

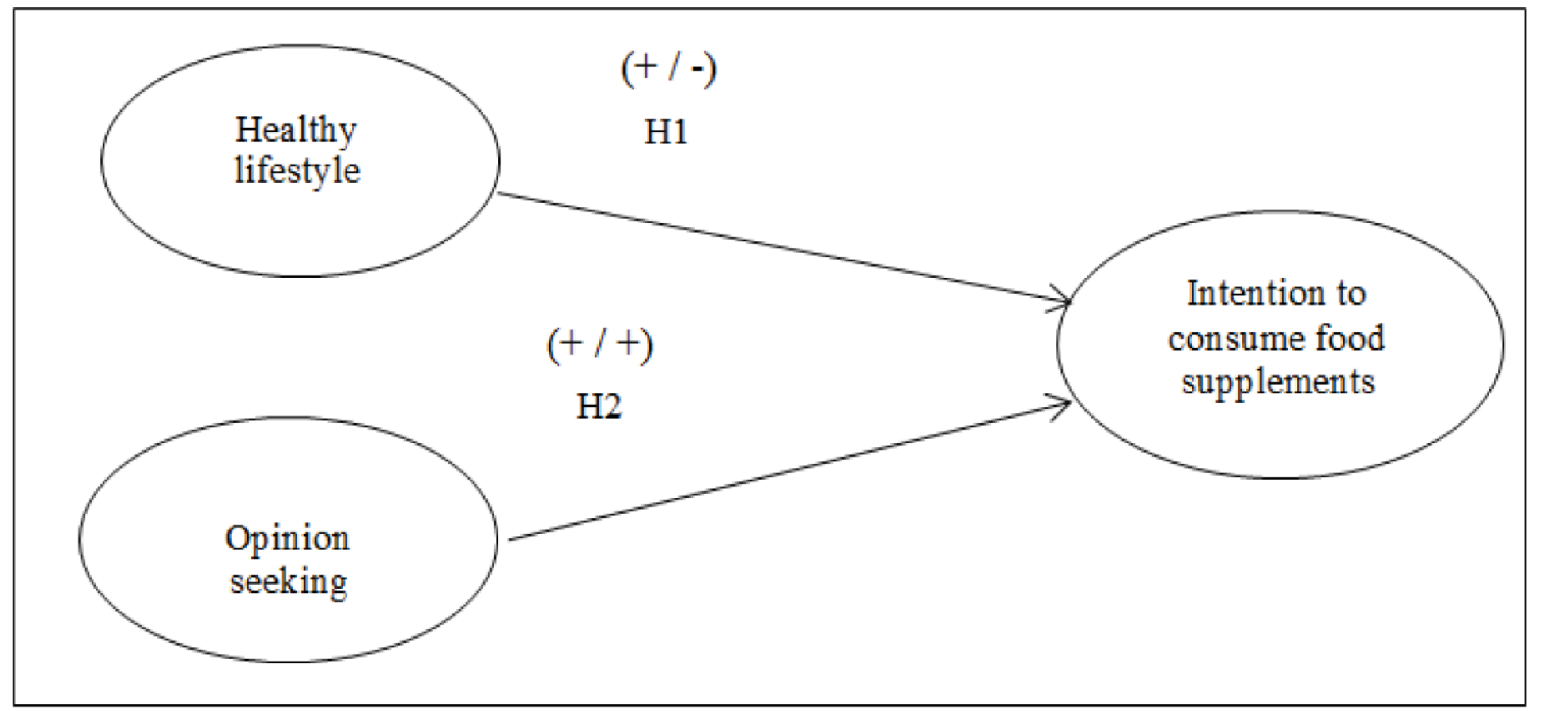

Source: Elaborated by the authors.

\section{METHOD}

To verify the objective proposed by the present work, and to examine the suggested theoretical model, a quantitative descriptive research was carried out (Malhotra, 2006). This type of approach is based on post-positivism and performed a thorough analysis of the object of study. At first, a bibliographic survey was made using the Science Direct, Scopus, Web of Science, Proquest and SciELO. In order to investigate the influence of the independent variables $\mathrm{HL}$ and OS on the dependent variable ICFS, a field survey was carried out with the search strategy as an online survey (Leeuw, Hox \& Dilman, 2008). 


\section{Population and sample}

The study was conducted in Brazil and during the second semester of 2019. The study population was composed of Brazilian youth and adults between 18 and 53 years of age. The sample of this research is presented as non-probabilistic (Babbie, 1999), since it was not possible to present a picture that represented the universe as a whole. With that, it is understood that from the research findings it is not possible to have generalizations (Malhotra, 2006).

In the case of sample selection, convenience sampling was chosen (Malhotra, 2006). Additionally, participants were selected based on previously established criteria, such as: (1) internet access, (2) over 18 years of age and (3) knowledge about dietary supplements. In addition, the technique chosen to operationalize the research and enhance the dimensioning of the sample was snowball, given that this resource favors the reach of the study from the moment that, through a sharing network, the individuals sent the questionnaires to your acquaintances. In addition, a filter question was used in order to guarantee the internal validity of the study and to serve as an inclusion criterion, namely: "do you know what a food supplement is?".

\section{Data collection procedure}

A structured questionnaire, self-administered and developed through Google Forms, was adopted as a data collection instrument. This questionnaire was created with the purpose of ensuring that the questions could meet the research objective. In addition, the questionnaire contains ten items from the scales for the study and five sociodemographic questions.

Furthermore, based on the theoretical framework of the study, in addition to the elaborated questionnaire, it was possible to confirm the use of scales related to the research constructs. The scales chosen were those of the Healthy Lifestyle constructs, developed by Downes (2008), and of Opinion Seeking, developed by Flynn, Goldsmith and Eastman (1996). The dependent variable, intention to consume food supplements, was measured based on the elaboration of a single item, developed by the authors.

In addition, all constructs were measured using the Likert scale, with a score from 1 (strongly disagree) to 7 (strongly agree). Below, in order to facilitate the understanding about the operationalization of data collection, a table with the item, authors and constructs listed in the research will be presented: 
Table 1. Base of the collection instrument

\begin{tabular}{|c|c|c|c|}
\hline Construct & Author & Items & Cod. \\
\hline $\begin{array}{l}\text { Intention to } \\
\text { consume food } \\
\text { supplements }\end{array}$ & $\begin{array}{l}\text { Own } \\
\text { authorship } \\
\text { (2019) }\end{array}$ & $\begin{array}{l}\text { 1. I plan to consume food supplements next month (such } \\
\text { as, thermogenic, Whey Protein, vitamin compounds, } \\
\text { essential fatty acids, etc.). }\end{array}$ & ICFS1 \\
\hline $\begin{array}{l}\text { Healthy } \\
\text { lifestyle }\end{array}$ & $\begin{array}{l}\text { Adapted from } \\
\text { Downes } \\
(2008)\end{array}$ & $\begin{array}{l}\text { 1. I participate in moderate physical activities, such as } \\
\text { running, cycling, walking or swimming } 30 \text { minutes, five } \\
\text { to seven days a week. } \\
\text { 2. I eat } 2 \text { pieces / serving of fruit a day. } \\
\text { 3. I eat vegetables every day. } \\
\text { 4. I usually avoid foods high in fat and calories such as } \\
\text { potato chips, soda pop or fatty meats. }\end{array}$ & $\begin{array}{l}\text { HL2 } \\
\text { HL3 } \\
\text { HL4 }\end{array}$ \\
\hline $\begin{array}{l}\text { Opinion } \\
\text { Seeking }\end{array}$ & $\begin{array}{l}\text { Adapted from } \\
\text { Flynn, } \\
\text { Goldsmith } \\
\text { and Eastman } \\
\text { (1996) }\end{array}$ & $\begin{array}{l}\text { 1. When I consider consuming dietary supplements, I ask } \\
\text { other people for advice. } \\
\text { 2. I don't need to talk to other people before I take food } \\
\text { supplements. } \\
\text { 3. Other people influence my choice regarding dietary } \\
\text { supplements. } \\
\text { 4. I would not choose a food supplement without } \\
\text { consulting someone else. } \\
\text { 5. I know enough about dietary supplements to the point } \\
\text { that I don't need other people's opinions. }\end{array}$ & $\begin{array}{l}\text { OS1 } \\
\text { OS2 } \\
\text { OS3 } \\
\text { OS4 } \\
\text { OS5 }\end{array}$ \\
\hline
\end{tabular}

Source: Elaborated by the authors (2020)

\section{Data analysis procedures}

For data analysis, the IBM SPSS software was used. Thus, basic descriptive statistics, distributed among frequency, percentage, average and standard deviation, were used to describe the sample's sociodemographic profile. Then, the subsequent phase was used to infer the results. Seeking to corroborate or refute the hypotheses proposed by the theoretical model, multiple linear regression analysis was used.

\section{Results and discussion}

At first, in order to find possible errors during the data collection process, the resulting questionnaires were reviewed. In addition, the mandatory filling of items on the Google Forms platform was used, with the purpose of eradicating the error of non-response (Leeuw, Hox \& Dillman, 2008). The confirmation of the success of this strategy occurred at the review stage. Thus, the items in the questionnaires were considered in their entirety, which contributed to the fact that all questionnaires answered were validated as components of the final sample $(n=130)$. Then, after proving the usefulness of the answered questionnaires, this material was treated in Excel so that, finally, the database could be imported into the SPSS, followed by the analyzes carried out with the help of this software. The hypotheses were evaluated using multiple linear regression, based on the equation " $y$ $=b 0+b 1 \times 1+b 2 \times 2+\ldots+b k x k+e^{\prime \prime}$, where the response $y$ is a function of $k$ predictive variables $x 1$, $\mathrm{x} 2, \ldots, \mathrm{xk}$. 


\section{Sociodemographic profile of respondents}

From the use of simple descriptive statistics, at first, it was intended to outline the respondents' sociodemographic profile. Therefore, based on the instrument's questions directed to this end, a percentage survey of the synthesized demographic information was carried out, as will be seen below in Table 2. Most of the subjects represented by the sample of this research are male, corresponding to $54 \%$ of the total. But the level of education of respondents is, pre-eminently, higher education (52,3\%). As for the Brazilian region that stands out in the research, there is a predominance of the Northeast, a fact that can be justified according to the place of origin of the study.

Furthermore, it was also considered pertinent, given the object of investigation proposed here, to identify whether the individual currently consumes dietary supplements and what is the main source of opinion seeking in the case of products of this kind. According to the results obtained, the majority, $54 \%$ of the total, say they consume food supplements today. Of these, $54,6 \%$ of the subjects stated that they resort to qualified professionals, such as nutritionists and doctors, to be advised on dietary supplementation. In contrast, the other respondents demonstrated that they have different sources of the main opinion seeking channels categorized into: Digital influencers $(16,2 \%)$, friends and family $(15,4 \%)$ and Gym instructors / personal trainer $(13,8 \%)$.

Table 2 - Sociodemographic profile based on frequencies, means and standard deviation

\begin{tabular}{|c|c|c|c|c|}
\hline \multicolumn{3}{|c|}{ Complete education level } & \multicolumn{2}{|l|}{ Genre } \\
\hline \multicolumn{2}{|c|}{ University education } & $52,3 \%$ & Male & $54 \%$ \\
\hline \multicolumn{2}{|l|}{ Postgraduate studies } & $28,5 \%$ & Feminine & $46 \%$ \\
\hline \multicolumn{2}{|l|}{ High school } & $19,2 \%$ & \multicolumn{2}{|c|}{ Marital status } \\
\hline Variables & Average & $\begin{array}{l}\text { Standard } \\
\text { deviation }\end{array}$ & Not married & $68,2 \%$ \\
\hline$\overline{\text { Age }}$ & 27,50 & 6,795 & Married & $22,5 \%$ \\
\hline Individual income & $\mathrm{R} \$ 2.134,22$ & $\mathrm{R} \$ 4.567,23$ & Divorced & $6,3 \%$ \\
\hline Family income & $\mathrm{R} \$ 4.235,66$ & $\mathrm{R} \$ 9.321,45$ & Other & $3,0 \%$ \\
\hline
\end{tabular}

Source: Elaborated by the authors (2020)

After the exposure of the sample's sociodemographic profile, the following statistical work was directed to the analysis of the consistency of the items that composed the questionnaire, followed by the dimensionality of the data. From that outside, the next session will try to present these results, prerequisites for carrying out the multiple regression analysis.

\section{Analysis of the proposed theoretical model}

As a necessary procedure for carrying out the regression method, the items that made up the constructs of the work were grouped as composite variables. The table 3 summarizes the theoretical model. 
Table 3. Summary of the model.

\begin{tabular}{|c|c|c|c|c|c|}
\hline Model & $\mathbf{R}$ & $R^{2}$ & $\begin{array}{c}\quad R^{2} \\
\text { Adjusted }\end{array}$ & $\begin{array}{c}\text { Estimate of } \\
\text { standard } \\
\text { error }\end{array}$ & Durbin -Watson \\
\hline 1 & 0,371 & 0,137 & 0,124 & 2,242 & 2,059 \\
\hline
\end{tabular}

Source: Elaborated by the authors (2020)

The value of $\mathrm{R}$, which corresponds to 0,371 , indicates a correlation between the independent variables and the dependent variable. This coefficient of determination, according to Fávero et al. (2009), can be understood as the proportion of the total variation in the intention to purchase food supplements, explained by the independent variables. In the case of this investigation, specifically, the independent variables explain $13,7 \%$ of the purchase intention, a value measured from $\boldsymbol{R}^{2}$. However, it is the adjusted $\boldsymbol{R}^{2}$ value that must be considered to explain the relationships between the independent and dependent variables. This is because the index proposes a correction of the determination coefficient in cases where there is more than one independent variable. In this study, the adjusted $\boldsymbol{R}^{2}$ value is 0,124 , with the standard error estimate of 2,059.

In the Table 4 (Coefficients) the variable opinion seeking presented a Sig. value in the multiple regression of 0,081 , which represents that its influence, as an independent variable, was marginally accepted, since in this study Sig. is considered $t<0,05$ as a reference standard. Thus, confirming hypothesis $\mathrm{H} 2$. Nevertheless, the healthy lifestyle variable (HL) scored within the established parameters, proving its influence on the intention to purchase food supplements. However, this result refutes the $\mathrm{H} 1$ hypothesis, since the values presented by this variable have opposite meanings to those proposed by $\mathrm{H} 1$. Finally, the table below shows the coefficients of the multiple regression analysis and which support the findings of the hypotheses raised in the research.

Table 4. Coefficients.

\begin{tabular}{|c|c|c|c|c|c|c|c|}
\hline \multirow{2}{*}{ Model } & \multicolumn{2}{|c|}{$\begin{array}{l}\text { Nonstandard } \\
\text { coefficients }\end{array}$} & \multirow{2}{*}{$\begin{array}{c}\begin{array}{c}\text { Standardized } \\
\text { coefficient }\end{array} \\
\text { B }\end{array}$} & \multirow{2}{*}{$\mathbf{T}$} & \multirow{2}{*}{ Sig . } & \multicolumn{2}{|c|}{$\begin{array}{l}\text { 95\% confidence } \\
\text { interval for } B\end{array}$} \\
\hline & B & $\begin{array}{l}\text { Standard } \\
\text { error }\end{array}$ & & & & $\begin{array}{l}\text { Inf. } \\
\text { Limit }\end{array}$ & $\begin{array}{l}\text { Sup. } \\
\text { Limit }\end{array}$ \\
\hline (Constant) & 0,566 & 1,096 & & 0,516 & 0,607 & $-1,603$ & 2,734 \\
\hline Healthy lifestyle & 0,551 & 0,129 & 0,352 & 4,257 & 0,000 & 0,295 & 0,807 \\
\hline Opinion Seeking & 0,326 & 0,185 & 0,145 & 1,760 & 0,081 & $-0,041$ & 0,692 \\
\hline
\end{tabular}

Source: Elaborated by the authors (2020)

Tests were also carried out with the variables of the demographic profile, such as control variables. Thus, with the inclusion of the variables age $(b=-0.003 ; t=0.044 ; p>0.05)$ and income $(B=$ $-0.005 ; t=0.075 ; p>0.05$ ) in the regression model, there was no change in the previous result of the independent variables. In addition, the sex and education variables were transformed into dummy to also be included in the model as control variables. And, as with the other two tested variables of the demographic profile, $\operatorname{sex}(b=-0.418 ; t=-1.297 ; p>0.05)$ and education $(b=-0.239 ; t=-1.060$; $p>0.05$ ) did not show statistically significant influences on the consumption of dietary supplements and did not change the previous results.

From the results exposed and explained, it appears that hypotheses $\mathrm{H} 1$ and $\mathrm{H} 2$ were, re- 
spectively, rejected and confirmed. The non-confirmation of $\mathrm{H} 1$, based on statistical data, reveals: individuals who have a higher level of healthy lifestyle are likely to consume food supplements. Thus, this result is in line with the findings of Bandura (2004) and Stafford (2016) who state that individuals who have healthy habits seek to consume food supplements as a way to avoid a negative and unwanted health status. Converging with this approach, according to Dickinson, Blatman, El-Dash and Franco (2014), food supplements are seen as safe and effective products to keep their consumers healthy, which explains the consumption of such products by those who have a healthy lifestyle.

In this perspective, it is suggested that subjects with a healthy lifestyle and who are intent on buying dietary supplements, may be being induced, for example, by the media or by reference groups (Herman, 2015) when these products are advertised as promoters of health and well-being, as shown in the work of Pawar and Grundel (2017). In line with this idea, there are studies by Küster-Boluda and Vidal-Capilla (2017), Azila Mohd Noor et al (2014) and Hartmann and Siegrist (2016) when they found that the main reason that leads young people to consume food supplements it is the fact that they believe that such products have a well-being and positive effect on health. In addition, the $\mathrm{H} 2$ denial endorses the result of the work of Foote et al. (2003), where 100,196 people were interviewed to identify factors associated with the consumption of supplements, the results provided evidence that in addition to age and education, physical activity and healthy habits are linked to a higher consumption of nutritional supplements.

Thus, it is understood that these individuals, despite having an influential level of healthy lifestyle, may be subject to the risk of damage to health due to the consumption of these products. Corroborating this statement, the survey data revealed that almost $50 \%$ of respondents who consume dietary supplements have this practice without the guidance of a professional able to direct this consumption. Thus, for Foote (2003), although consumers of dietary supplements are generally more careful with their nutritional intake, there is a tendency for these users to exceed nutritional recommendations and, therefore, excessive consumption of supplements can be a health threat. Converging with this position is the study by Burnett et al. (2017) carried out among young Australians.

Moreover, it understands that, although it is possible for physically active individuals get their needs daily nutrients through the consumption of natural and healthy food for Jäger et al. (2017) supplementation would be an attempt at a practical and easy action to ensure the intake of these nutrients. Despite this, it is seen in the study by Ewan et al. (2019) that, in the case of those who practice weight training, in general, their results provide evidence that gym users have inadequate knowledge about their nutritional needs, which generates the inadequate consumption of products for food supplementation. Therefore, the $\mathrm{H} 1$ denial confirms that even those who have a healthy lifestyle are potentially exposed to the health risks that consumption of dietary supplements causes.

Regarding $\mathrm{H} 2$, the results converged for confirmation, which implies that the level of opinion seeking influences the intention to consume food supplements. Therefore, individuals who seek an opinion have a greater intention to consume products in this category, considering that there may previously be a favorable attitude towards the consumption of such products in these subjects. In addition, as seen in the studies by Stafford (2016) and DeLorme et al. (2012), in the food supplement market, due to the influence of advertising and consumers, consumers are confused and therefore tend to look for information from other sources to minimize the subjective perception of the risks associated with the consumption of such products.

However, the results also show that $45,4 \%$ of respondents say that their main sources of information are not from health professionals, such as nutritionists and doctors, who technically would be able to guide this consumption. Thus, it is understood that this opinion seeking, in fact, 
becomes a risk factor when associated with a source not able to correctly guide the purchase and consumption of these products. Converging with these findings, studies by Whitehouse and Lawlis (2017) reveal that the gym technician / instructor would be the main source of information for targeting individuals, especially young people who practice physical activities, when it comes to the use of dietary supplements, followed by each person's personal choice based on information from surveys conducted over the internet.

As implications of this result, it is understood that, according to the study by Hartmann and Siegrist (2016), an inadequate primary source of information about dietary supplementation may lead users of dietary supplements to not know the risks and associated side effects excessive consumption of this product, which increases the possibility of damage to the user's health. In view of this finding, the study by Attlee et al. (2017) indicates that the responsibility on the part of those who are influential figures (opinion leaders) in the lives of those who seek information about dietary supplements, such as technicians and family members, is of fundamental importance.

In short, instructors or friends who are not instructed to direct the dietary supplementation of others, can provide inaccurate, inappropriate or potentially harmful health advice. Thus, the opinion seeking influences the intention to consume food supplements, but it also tends to potentiate the risks associated with the consumption of these products since, commonly, opinion leaders are not able to direct the dietary supplementation of the influenced subject. Once these discussions have been raised, the next session is intended to present the main conclusions of the work, followed by limitations and suggestions for future investigations.

\section{CONCLUSIONS}

The aim of this study was to verify the influence of a healthy lifestyle and the opinion seeking in relation to the intention to consume food supplements. For this, this research, carried out from an inferential quantitative approach, came to some conclusions. At first, it is important to highlight that, although a healthy lifestyle can be represented by a set of actions such as regular physical activity and a diet based on healthy foods, healthy lifestyle exerted, in this case, a significant influence on the intention to consume food supplements.

Thus, the main contribution of this research is that a healthy lifestyle based on a diet based on fruits, vegetables and proteins and with the practice of regular physical activities does not represent the absence of consumption of dietary supplements. On the contrary, in this research, it was found that the higher the level of healthy lifestyle, the greater the intention to resort to dietary supplementation.

The opinion-seeking construct, in turn, positively influences the intention to consume food supplements. However, for the research sample, this opinion seeking is intrinsically related to the search for information by sources not indicated to direct the consumption of dietary supplements. Thus, it is concluded that opinion seeking from the consumer can contribute to minimize the subjective perception of the risk of damage to health. However, depending on the information source of this opinion seeking, the objective risk increases: consuming the product improperly.

Therefore, it is assumed that consumers of dietary supplements are not always aware of the damage that these products can cause to health, constituting a public health challenge. Therefore, in order to raise awareness among the population, it is understood that education policies that show the risks associated with the consumption of products of this nature, as well as encouraging the search for qualified professionals to guide dietary supplementation, are understood as strategies for promotion health and well-being. 


\section{Practical implications}

Based on the results of the research, it is understood that there is a high number of people consuming food supplements on their own initiative or without the proper recommendation from a specialized professional, which represents a public health problem and serves as a warning for the performance of companies and authorities. Therefore, as seen in the text, in 2018, the country's first regulation on these products was created. However, little is known about this legal framework, that could gain greater visibility through the media d the s public officials and the private sector. In addition, there is a significant number of such products on the market, which makes inspection difficult, with the lack of security for consumer health being the greatest risk associated with this scenario. Thus, it is understood that inspection policies for this segment should be more conspicuous.

Furthermore, due to the use of advertisements with exaggerated claims about the effects of dietary supplements, these commercial appeals aim to induce the consumer to purchase or, further, to promote the false image that the product is effective. This often occurs with the announcement of the presence of ingredients from plants, vitamins and minerals in the samples, creating the image of a natural product. Thus, the consumer is not always aware of the damage that these substances, even natural, can cause. Therefore, it is up to the companies in this segment to invest in research and technology to the point of offering a good that their customers, from scientific data, know the risks associated with the consumption of these products.

\section{Limitations and suggestions for future research}

Regarding the limitations of the research, it is understood that the sample concentration was in the Northeast region, thereby reducing the representativeness of the Brazilian population. This, however, can be justified depending on the place of origin of the study.

In light of the above, some provocations are raised as suggestions for future studies. At first, it is necessary to investigate in a more robust and targeted way the reasons why the healthy lifestyle has shown a relevant influence as an antecedent factor of the intention to consume food supplements. In addition, it is also possible to test the relevance of the same theoretical model proposed, however, adding the construct consumer attitude towards food supplements, as the predecessor of the opinion seeking, in order to better understand what leads consumers to seek opinions on products of that nature.

\section{REFERENCES}

ALKHATIB, A., SEIJO, M., LARUMBE, E., \& NACLERIO, F. (2015). Acute effectiveness of a "fat-loss" product on substrate utilization, perception of hunger, mood state and rate of perceived exertion at rest and during exercise. Journal of the International Society of Sports Nutrition, 12 (1). doi: 10.1186 / s12970-015-0105-8

ASSAEL, HENRY. (1987). Consumer Behavior \& Marketing Action. 4th ed. Boston: PWS-Kent.

Brazilian Association of Manufacturers of Nutritional Supplements and Foods for Special Purposes. Figures for the food supplement sector. São Paulo: BrasNutri; 2019. Available at: http://www. brasnutri.org.br 
ATTLEe, A., HAIDER, A., HASSAN, A., ALZAMIL, N., HASHIM, M., \& OBAID, RS. (2017). Dietary Supplement Intake and Associated Factors Among Gym Users in a University Community. Journal of Dietary Supplements, 15 (1), 88-97. doi: 10.1080 / 19390211.2017 .1326430

AZILA MOHD NOOR, N., YAP, S.-F., LIEW, K.-H., \& RAJAH, E. (2014). Consumer attitudes toward dietary supplements consumption. International Journal of Pharmaceutical and Healthcare Marketing, 8 (1), 6-26. doi: 10.1108 / ijphm-04-2013-0019

BABBIE, E. (1999). Survey research methods. Belo Horizonte: Editora da UFMG.

BANDURA, A. (2004). Health Promotion by Social Cognitive Means. Health Education \& Behavior, 31 (2), 143-164. doi: 10.1177 / 1090198104263660

BESSADA, SMF, ALVES, RC, \& OLIVEIRA, MBPP. (2018). Caffeine-based food supplements and beverages: Trends of consumption for performance purposes and safety concerns. Food Research International, 109, 310-319. doi: 10.1016 / j.foodres.2018.04.050

BURNETT, A., LIVINGSTONE, K., WOODS, J., \& MCNAUGHTON, S. (2017). Dietary Supplement Use among Australian Adults: Findings from the 2011-2012 National Nutrition and Physical Activity Survey. Nutrients, 9 (11), 1248. doi: 10.3390 / nu9111248

BRAZIL, MINISTRY OF HEALTH. (2017). Vigitel Brasil 2016: surveillance of risk and protective factors for chronic diseases by telephone survey. Secretariat of health surveillance, Department of surveillance of non-communicable diseases and conditions and health promotion - $160 \mathrm{f}$. Brasília: Federal Government.

BrasNutri Online. (2019). Available at: mandomodernmanual.com. $\mathrm{Br}$ / fitness / best-selling-fatburner-supplements-in-brazil (accessed Nov 12, 2019).

CHANDON, P., \& WANSINK, B. (2007). The Biasing Health Halos of Fast-Food Restaurant Health Claims: Lower Calorie Estimates and Higher Side-Dish Consumption Intentions. Journal of Consumer Research, 34 (3), 301-314. doi: 10.1086 / 519499

DELORME, DE, HUH, J., REID, LN, \& AN, S. (2012). Dietary supplement advertising in the US. International Journal of Advertising, 31 (3), 547-577. doi: 10.2501 / ija-31-3-547-577

DICKINSON, A., BLATMAN, J., EL-DASH, N., \& FRANCO, JC (2014). Consumer Usage and Reasons for Using Dietary Supplements: Report of a Series of Surveys. Journal of the American College of Nutrition, 33 (2), 176-182. doi: 10.1080 / 07315724.2013 .875423

DOWNES, L. (2008). Motivators and Barriers of a Healthy Lifestyle Scale: Development and Psychometric Characteristics. Journal of Nursing Measurement, 16 (1), 3-15. doi: 10.1891 / 1061-3749.16.1.3

ENGEL, JAMES F., ROGER D. BLACKWELL, \& PAUL W. MINIARD. (nineteen ninety). Consumer Behavior. 6th ed. Chicago: Dryden.

Euromonitor (2019). Dietary Supplements in Brazil. Global Market Information Database, available at: www.euromonitor.com (accessed Nov 14, 2019).

EWAN, T., BetTINA, K., fATMA NESE, S., GOKTUG, E., FRANCESCO, M., VINCENZA, L. ,... ANTONINO, B. (2019). Protein supplement consumption is linked to time spent exercising 
and high-protein content foods: A multicentric observational study. Heliyon, 5 (4), e01508. doi: 10.1016 / j.heliyon.2019.e01508

FOOTE, JA (2003). Factors Associated with Dietary Supplement Use among Healthy Adults of Five Ethnicities: The Multiethnic Cohort Study. American Journal of Epidemiology, 157 (10), 888897. doi: 10.1093 / aje / kwg072

FLYNN, LR, GOLDSMITH, RE, \& EASTMAN, JK. (1996). Opinion Leaders and Opinion Seekers: Two New Measurement Scales. Journal of the Academy of Marketing Science, 24 (2), 137-147.doi: 10.1177 / 0092070396242004

FRIEDMAN, J., BIRSTLER, J., LOVE, G., \& KIEFER, D. (2019). Diagnoses associated with dietary supplement use in a national dataset. Complementary Therapies in Medicine, 43, 277-282. doi: 10.1016 / j.ctim.2019.02.016

FULLER- TYSZKIEWICZ, M., BROADBENT, J., RICHARDSON, B., WATSON, B., KLAS, A., \& SKOUTERIS, H. (2020). A network analysis comparison of central determinants of body dissatisfaction among pregnant and non-pregnant women. Body Image, 32, 111-120. doi: 10.1016 / j.bodyim.2019.12.001

HAIR, JF, BLACK, WC, BABIN, BJ, ANDERSON, RE, \& TATHAM, RL. (2009). Multivariate analysis of data. Porto Alegre: Bookman.

HARTMANN, C., \& SIEGRIST, M. (2016). Benefit beliefs about protein supplements: A comparative study of users and non-users. Appetite, 103, 229-235.

HERMAN, CP. (2015). The social facilitation of eating. The review. Appetite, 86, 61-73. doi: 10.1016 / j.appet.2014.09.016

JÄGER, R., KERKSICK, CM, CAMPBELL, BI, CRIBB, PJ, WELLS, SD, SKWIAT, TM,... ANTONIO, J. (2017). International Society of Sports Nutrition Position Stand: protein and exercise. Journal of the International Society of Sports Nutrition, 14 (1).

JAIN, L., \& KATARYA, R. (2019). Discover opinion leader in online social network using firefly algorithm. Expert Systems with Applications, 122, 1-15. doi: 10.1016 / j.eswa.2018.12.043

KÜSTER-BOLUDA, I., \& VIDAL-CAPILLA, I. (2017). Consumer attitudes in the election of functional foods. Spanish Journal of Marketing - ESIC, 21, 65-79.

LEEUW, ED, HOX, JJ, \& DILLMAN, DA (2008). Mixed-mode surveys: When and why. International handbook of survey methodology, 299-316.

LI, A. S. K., \& HU, T. Y. (2018). Are immediate-oriented people unlikely to adopt a healthy lifestyle? The moderation effect of prevention focus. Personality and Individual Differences. doi: 10.1016 / j.paid.2018.10.004

LUQIU, LUWEI \& SCHMIERBACH, MICHAEL \& NG, YU- LEUNG. (2019). Willingness to follow opinion leaders: A case study of Chinese Weibo. Computers in Human Behavior. 101. 10.1016 / j. chb. 2019.07.005.

MAI, R., \& HOFFMANN, S. (2012). Taste lovers versus nutrition fact seekers: How health consciousness and self-efficacy determine the way consumers choose food products. Journal of Consumer 
Behavior, 11 (4), 316-328. doi: 10.1002 / cb.1390

MALHOTRA, NK (2006). Search Marketing: A orientaçã the applied. 4. ed. Porto Alegre : Bookman.

MARQUES, A., PERALTA, M., SANTOS, T., MARTINS, J. , \& GASPAR DE MATOS, M. (2019). Selfrated health and health-related quality of life are related to adolescents' healthy lifestyle. Public Health, 170, 89-94. doi: 10.1016 / j.puhe.2019.02.022

Merriam-Webster Online. (2019). available at: www.merriam-webster.com/dictionary/supplement (accessed Nov 10, 2019).

Ministry of Health of Brazil. (2018). National Health Surveillance Agency. RDC $n 0$ 243, of July 26, 2018. Provides for the health requirements of food supplements. Diário Oficial União. $27 \mathrm{Jul}$ 2018; Section 1: 100.

MOLIN, TRD, LEAL, GC, MURATT, DT, MARCON, GZ, CARVALHO, LM DE, \& VIANA, C. (2019). Regulatory framework for dietary supplements and the public health challenge. Revista de Saúde Pública, 53, 90. doi: 10.11606 / s1518-8787.2019053001263

OR, F., KIM, Y. , SIMMS, J., \& AUSTIN, SB (2019). Taking Stock of Dietary Supplements' Harmful Effects on Children, Adolescents, and Young Adults. Journal of Adolescent Health. doi: 10.1016 / j.jadohealth.2019.03.005

World Health Organization. (2000). Obesity: Prevention and management of the global epidemic: Report from a WHO consultation. WHO technical report series, 894.

HOMER, PM, \& MUKHERJEE, S. (2018). The impact of dietary supplement form and dosage on perceived efficacy. Journal of Consumer Marketing, 35 (2), 228-238. doi: 10.1108 / jcm-022017-2108

PAWAR, RS, \& GRUNDEL, E. (2016). Overview of regulation of dietary supplements in the USA and issues of adulteration with phenethylamines (PEAs). Drug Testing and Analysis, 9 (3), 500517. doi: 10.1002 / dta.1980

PUNJ, GIRISH \& STAELIN, RICHARD. (1983). A Model of Consumer Information Search for New Automobiles. Journal of Consumer Research. 9. 366-80. 10.1086 / 208931.

ROCHA, T., AMARAL, JS AND OLIVEIRA, MBP (2016). Adulteration of Dietary Supplements by the Illegal Addition of Synthetic Drugs: A Review. Comprehensive Reviews in Food Science and Food Safety, 15: 43-62. doi: 10.1111 / 1541-4337.12173

SAPER, RB, EISENBERG DM, \& PHILLIPS, R, S. (2004). Common dietary supplements for weight loss. Am Fam Physician. 70: 173, 1-8.

SARWER, DB, CASH, TF, MAGEE, L., WILLIAMS, EF, THOMPSON, JK, ROEHRIG, M., ET AL. (2005). Female college students and cosmetic surgery: an investigation of experiences, attitudes, and body image. Plastic Reconstructive Surgery, 115, 931-938.

STARR, RR (2015). Too Little, Too Late: Ineffective Regulation of Dietary Supplements in the United States. American Journal of Public Health, 105 (3), 478-485. doi: 10.2105 / ajph.2014.302348

STICKEL, F., \& SHOUVAL, D. (2015). Hepatotoxicity of herbal and dietary supplements: an update. Archives of Toxicology, 89 (6), 851-865. 
SUH, YJ, \& LIM, EJ. (2014). The effect of Subjective consumer compe - tency on the consumer satisfaction in food- Focused on feeling of insecurity for food and type of household. Journal of Consumer Policy Studies, 45 (3), 131-156.

VAUGHAN, RA, WHITE, AC, BEAM, JR, GANNON, NP, GARCIA-SMITH, R., SALGADO, RM, MERMIER, CM (2017). Effect of novel dietary supplement on metabolism in vitro and in vivo. Journal of Traditional and Complementary Medicine, 7 (1), 1-8. doi: 10.1016 / j.jtcme.2015.03.008

WHITEHOUSE, G., \& LAWLIS, T. (2017). Protein supplements and adolescent athletes: A pilot study investigating the risk knowledge, motivations and prevalence of use. Nutrition \& Dietetics, 74 (5), 509-515.

WILLIS, E., \& ROYNE STAFFORD, M. (2016). Health consciousness or familiarity with supplement advertising. International Journal of Pharmaceutical and Healthcare Marketing, 10 (2), 130147. doi: 10.1108 / ijphm-06-2015-0026

ZANDSTRA, E., DE GRAAF, C., \& VAN STAVEREN, W. (2001). Influence of health and taste attitudes on consumption of low- and high-fat foods. Food Quality and Preference, 12 (1), 75-82. doi: 10.1016 / s0950-3293 (00) 00032-x

\section{AUTHORS}

\section{Jeferson Mendonça Pereira Filho}

Master's student in Management, Innovation and Consumption - PPGIC / UFPE, Production Engineer graduated from the Caruaruense Association of Higher Education (2018), specialist in Environmental Law and Sustainability from the Educational Faculty of Lapa (2018), has a degree in Administration from the Federal University of Pernambuco (2016).

E-mail: jefersonbetesda@hotmail.com

ORCID: https://orcid.org/0000-0002-3734-8831

\section{Marconi Freitas da Costa}

Adjunct Professor at the Federal University of Pernambuco - UFPE. PhD in Administration from FEA / USP. PhD in Administration from PROPAD / UFPE. Vice-Coordinator of the Post-Graduate Program in Management, Innovation and Consumption - PPGIC (Academic Master's Degree) at the Federal University of Pernambuco, Campus Caruaru. Permanent Professor of the Graduate Program in Administration - PROPAD / UFPE and the Graduate Program in Hospitality and Tourism - PPHTur / UFPE.

E-mail: marconi.fcosta@ufpe.br

Orcid: https://orcid.org/0000-0001-9888-8359

\section{Jonas Alves Cavalcanti}

Doctor of Accounting and Administration from University Bachelor of Business Administration with an Emphasis in Fashion Marketing from the University of Pernambuco - UPE; Gastronomer at the University Center UNIFAVIP DeVry. Post-graduated in Gastronomy and Authorial Cuisine at PUC-RS and Master's Degree in Management, Innovation and Consumption at UFPE-CAA.

E-mail: jonasalvesca@gmail.com

Orcid: https://orcid.org/0000-0001-6889-0802 


\section{Contribution of authors.}

Every author should account for at least one component of the work. Paper approved for publication need to specify the contribution of every single author.

\begin{tabular}{|l|c|c|c|}
\hline \multicolumn{1}{|c|}{ Contribution } & [Author 1] & [Author 2] & [Author 3] \\
\hline 1. Definition of research problem & $\mathrm{V}$ & $\mathrm{V}$ & $\mathrm{V}$ \\
\hline $\begin{array}{l}\text { 2. Development of hypotheses or research } \\
\text { questions (empirical studies) }\end{array}$ & $\mathrm{V}$ & $\mathrm{V}$ & \\
\hline $\begin{array}{l}\text { 3. Development of theoretical propositions } \\
\text { (theoretical work) }\end{array}$ & & & \\
\hline 4. Theoretical foundation / Literature review & $\mathrm{V}$ & $\mathrm{V}$ & \\
\hline 5. Definition of methodological procedures & $\mathrm{V}$ & $\mathrm{V}$ & $\mathrm{V}$ \\
\hline 6. Data collection & $\mathrm{V}$ & & \\
\hline 7. Statistical analysis & $\mathrm{V}$ & $\mathrm{V}$ & \\
\hline 8. Analysis and interpretation of data & $\mathrm{V}$ & & $\mathrm{V}$ \\
\hline 9. Critical revision of the manuscript & & $\mathrm{V}$ & \\
\hline 10. Manuscript writing & $\mathrm{V}$ & $\mathrm{V}$ & \\
\hline 11. Other (please specify) & & & \\
\hline
\end{tabular}

\section{Conflict of Interest}

The authors have stated that there is no conflict of interest.

\section{Copyrights}

ReA/UFSM owns the copyright to this content.

Plagiarism Check

The ReA/UFSM maintains the practice of submitting all documents approved for publication to the plagiarism check, using specific tools, e.g.: CopySpider. 